\title{
Interactive Letter and Number Learning Machines for Early Childhood
}

\author{
Mochamad Fajar Wicaksono ${ }^{* 1}$, Myrna Dwi Rahmatya ${ }^{2}$, Angga Rinaldi ${ }^{3}$ \\ ${ }^{1}$ Program Studi Teknik Komputer, Fakultas Teknik dan Ilmu Komputer, Universitas Komputer \\ Indonesia, \\ ${ }^{2}$ Program Studi Manajemen Informatika, Fakultas Teknik dan Ilmu Komputer, Universitas \\ Komputer Indonesia, \\ ${ }^{3}$ Program Studi Sistem Komputer, Fakultas Teknik dan Ilmu Komputer, Universitas Komputer \\ Indonesia \\ E-mail: ${ }^{* 1} \underline{\text { mfajarw@email.unikom.ac.id, }}{ }^{2}$ myrna@ email.unikom.ac.id, \\ angga.rinaldi93@gmail.com
}

\begin{abstract}
The purpose of this study is to design and create interactive learning machines for letters and numbers for early childhood. The machine designed is an interactive learning machine so that early childhood is interested in learning and can learn independently. Arduino Mega2560 is used as the main processor on this machine. On this machine, there are three modes, namely learning mode, question mode, and counting mode. In learning mode, Arduino will read every button input pressed, display on the LCD and make a sound through DF Player in accordance with the input received. In the question mode, Arduino will issue a question in the form of sound and wait for an answer via the input button found on the device. In arithmetic mode, Arduino will read the input of 10 LDR sensors covered by ice-cream sticks placed by young children and make sounds related to the amount. Questions on tools can be changed by using an android application designed in this study. Based on the test results, this tool has been running well where all modes can be run 100\% whether it is learning mode, question mode, and counting mode.
\end{abstract}

Keyword - Arduino, Early childhood, LCD, DF Player, Letters, and Numbers, Counting

\section{INTRODUCTION}

The early age or golden age of a child is in the range of 0 to 6 years wherein this age range the brain develops the fastest ${ }^{[1]}$. Therefore, early childhood education is very important because this determines the child's development. In this study an interactive learning machine of letters and numbers was designed and made for early childhood with three modes, namely learning mode, question mode and numeracy mode which aim to attract early childhood learning interests which in the end it is expected that young children know and remember each letter and numbers and are able to count simply. Research conducted on interactive learning tools of letters and numbers for early childhood was conducted in $2015^{[2]}$. The learning tools in the research have been going well, but in the study, there are no question features that can be changed by parents. The advantage of this machine learning is the problem features. Practice questions can be changed through the Android application and each question will be stored on the Arduino Mega2560 EEPROM. In the beginning, Arduino will wait for input related to the mode to be selected. If the selected mode is learning, then Arduino will wait for an input button from early childhood. The input button received will be processed by Arduino. Furthermore, Arduino displays letters pressed on the LCD and will give commands to the DF Player module to run mp3 files related to letters and numbers in accordance with the initial input that has been processed. If the selected mode is a question, then Arduino will read the EEPROM related to 10 questions that have been stored previously, the questions will be issued in the form of sound through the DF Player module and Arduino will wait for answers from early childhood. The process was repeated until ten 10 questions were answered. In this mode, each question has value. The final value will be mentioned in the form of sound by Arduino and each value will be sent to the application. It is intended that the teacher can see which questions cannot be answered. Furthermore, if the chosen mode is counting, Arduino will read the 
input related to which LDR sensor is covered by ice-cream sticks placed by early childhood. Placement of ice cream sticks on this machine can be done randomly. The number of closed sensor-related will be issued in the form of sound. It is hoped that this interactive learning machine can help young children to recognize and remember each letter and number so that this tool has a contribution to the world of education, especially early childhood education.

\section{RESEARCH METHODS}

The experimental method was used in this study with the stages of literature study, machine design, and application, simulation, implementation, and presentation related to experiments directly to test each function of this machine learning and finally the conclusion.

The literature study stage is carried out to look for theories related to the hardware and software needed to support the manufacture of this machine. The main design stage in this study is divided into two major parts, namely hardware design and software design. The hardware design is divided back into two parts namely the system block diagram section and the packaging design for this learning machine which includes the layout of numbers, letters, sensors, LCD, mode buttons and speakers. Figure 1 shows the top view position of this learning machine packaging design.

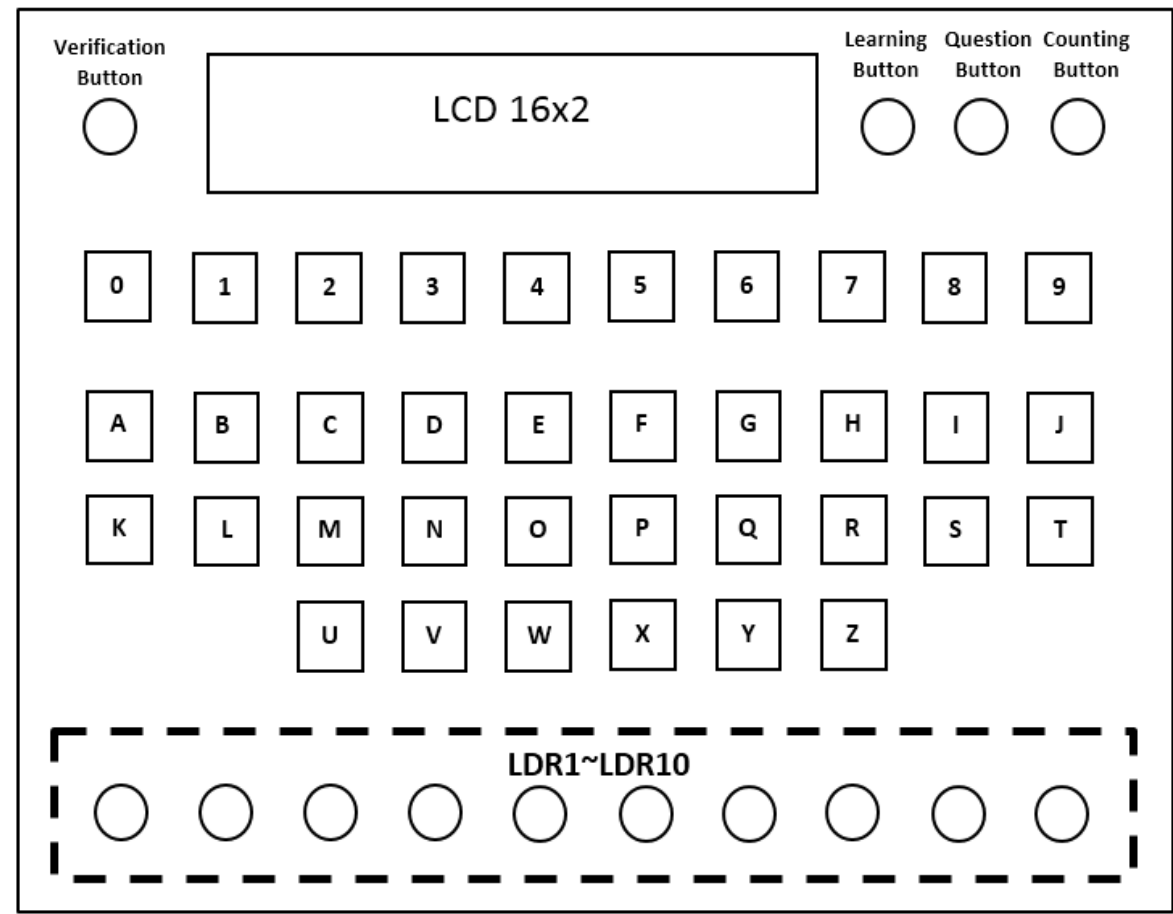

Figure 1. Top view of machine packaging design

Figure 1 shows the position of all components used as an interface with the user, in this case with early childhood. At the top, there is a $16 \times 2$ LCD that will display letters, numbers, and the number of ice cream sticks that cover the LDR sensor. At the top right there are 3 mode buttons, namely the learning mode button, question mode, and counting mode. In the middle, there is a sequence of $0 \sim 9$ number keys and the letters $\mathrm{A} \sim \mathrm{Z}$, while at the bottom there are $10 \mathrm{LDR}$ sensors used for counting mode. The interface of the other components is placed at the back. The rear view of this machine is shown in Figure 2.

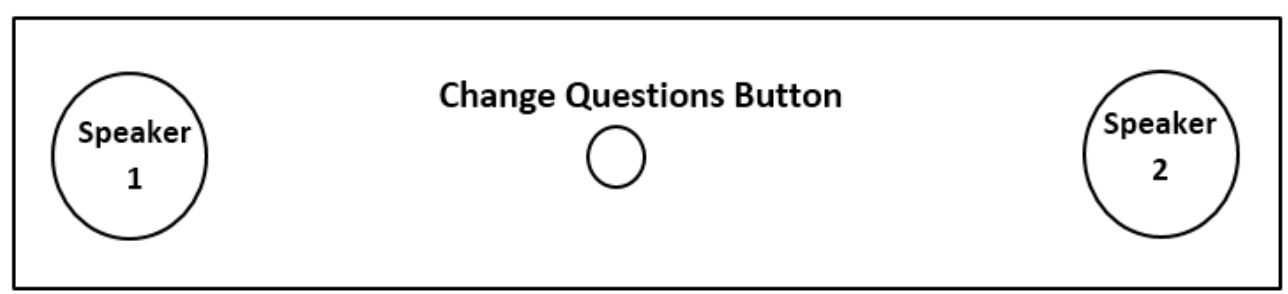

Figure 2. Bottom view of machine packaging design 
The button for changing the question is placed in the back section to avoid accidentally pressing the button by early childhood. Furthermore, the right and left sides of the rear position are filled by speaker1 and speaker2. The next step is designing a block diagram of the system. The overall block diagram of this interactive learning machine is shown in Figure 3.

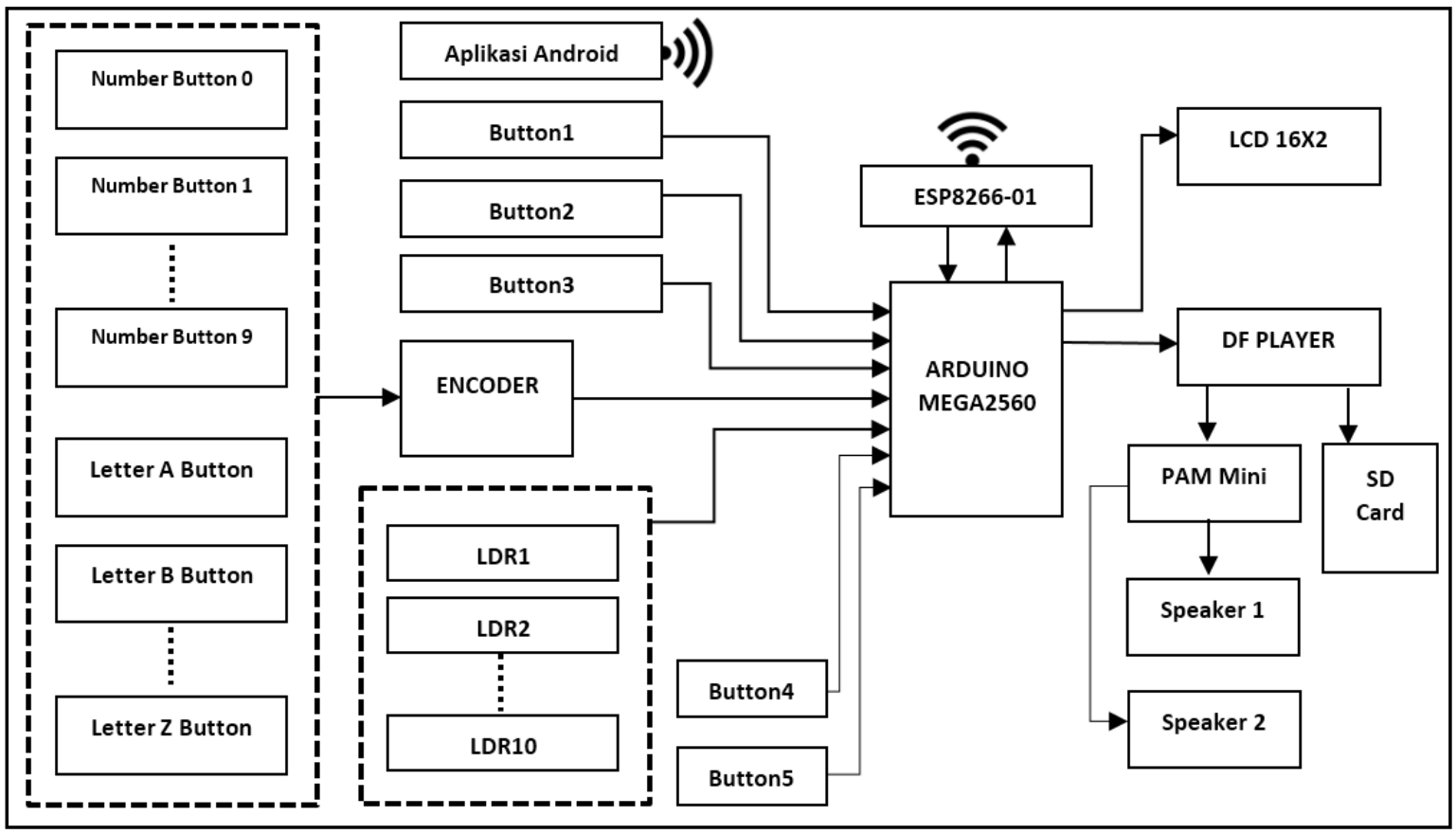

Figure 3. Interactive machine learning block diagram

Following are the functions and explanations of each section contained in the block diagram above:

1. Arduino Mega2560 is the main brain of this machine. Arduino is included in an open-source platform ${ }^{[3]}$. This Arduino Mega2560 uses ATMega2560 which is rich in peripherals equipped with 54 digital I / O pins, 16 analog pins, 4 pairs of UART, USB connection, reset button and ICSP header ${ }^{[4]}$. The compatibility of this board is also quite good because various shields for the Duemilanove or Diecimilia series can be installed and used for this board ${ }^{[5]}$. Figure 4 shows the physical form of the Arduino Mega2560.

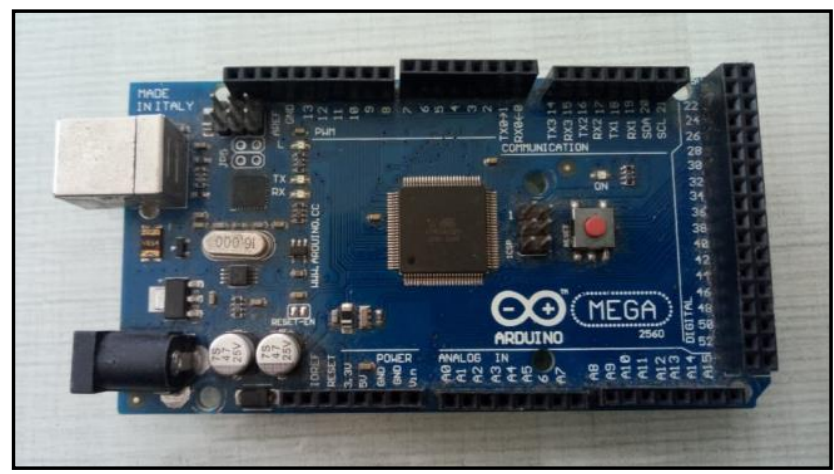

Figure 4. Arduino Mega2560

2. ESP8266-01 is an $\mathrm{SoC} \mathrm{WiFi}$ to a serial module with high performance but relatively inexpensive in terms of price ${ }^{[6]}$. This module requires a voltage of $3.3 \mathrm{~V}$ and a current of $250 \mathrm{~mA}$ to operate [6]. ESP8266-01 is used to receive data related to question changes sent from the Android application. Data received will be sent back to Arduino Mega2560.

3. LCD $16 \times 2$ on this system is used to display letters, numbers of each mode. The meaning of $16 \times 2$ on the LCD means that we can display 16 characters in one line and the number 2 indicates the number of lines on the $\mathrm{LCD}^{[7]}$. The Voltage Required for this LCD to be used is $5 \mathrm{~V}^{[8]}$.

4. LDR or Light Dependent Resistor is very useful in circuits that require sensors related to dark and bright light ${ }^{[9]}$. This LDR is made of semiconductor material where the characteristics of 
the material can change according to the intensity of the light regarding the LDR [10]. LDR1 LDR10 in this system is used in counting mode, where early childhood can put ice cream sticks either sequentially or randomly then Arduino will count the number of LDR covered by ice-cream sticks.

5. Number Button $1 \sim$ Number Button 10 is used for learning mode and question mode related to learning numbers in early childhood.

6. Letter A Button The Letter Z Button is used in the learning mode and question mode related to the learning of each letter in early childhood.

7. The encoder used is the priority encoder. This encoder will change the input into binary representations ${ }^{[11]}$. In this system, it is used to simplify the number of key inputs both numbers and letters so that it saves more use of the Arduino Mega2560 pin.

8. DFPlayer Mini on this system is used as a file player module with an mp3 extension. We can combine this module with Arduino by using serial communication. The serial pin voltage level on this module is $3.3 \mathrm{~V}^{[12]}$.

9. The PAM8403 module is an amplifier commonly used for sound amplifiers ${ }^{[13]}$. IC PAM8403 is categorized into a Class-D audio amplifier ${ }^{[14]}$. In this study, the PAM8403 module is used as an output amplifier for the DF Player module.

10. Button1 is used to select learning mode

11. Button2 is used to select the question mode

12. Button3 is used to select the counting mode.

13. Button4 is used to start the question change mode

14. Button5 is used for verification in the count mode

15. SD Card is used to storing mp3 files that will be played by DFPlayer Mini

16. Speaker 1 and Speaker 2 are used as loudspeakers related to sound in learning mode as well as sound-related questions.

17. Android application is used to update questions stored on Arduino Mega250

The next stage is software design which is described in the form of a flowchart. Figure 5 shows the mode selection flowchart.

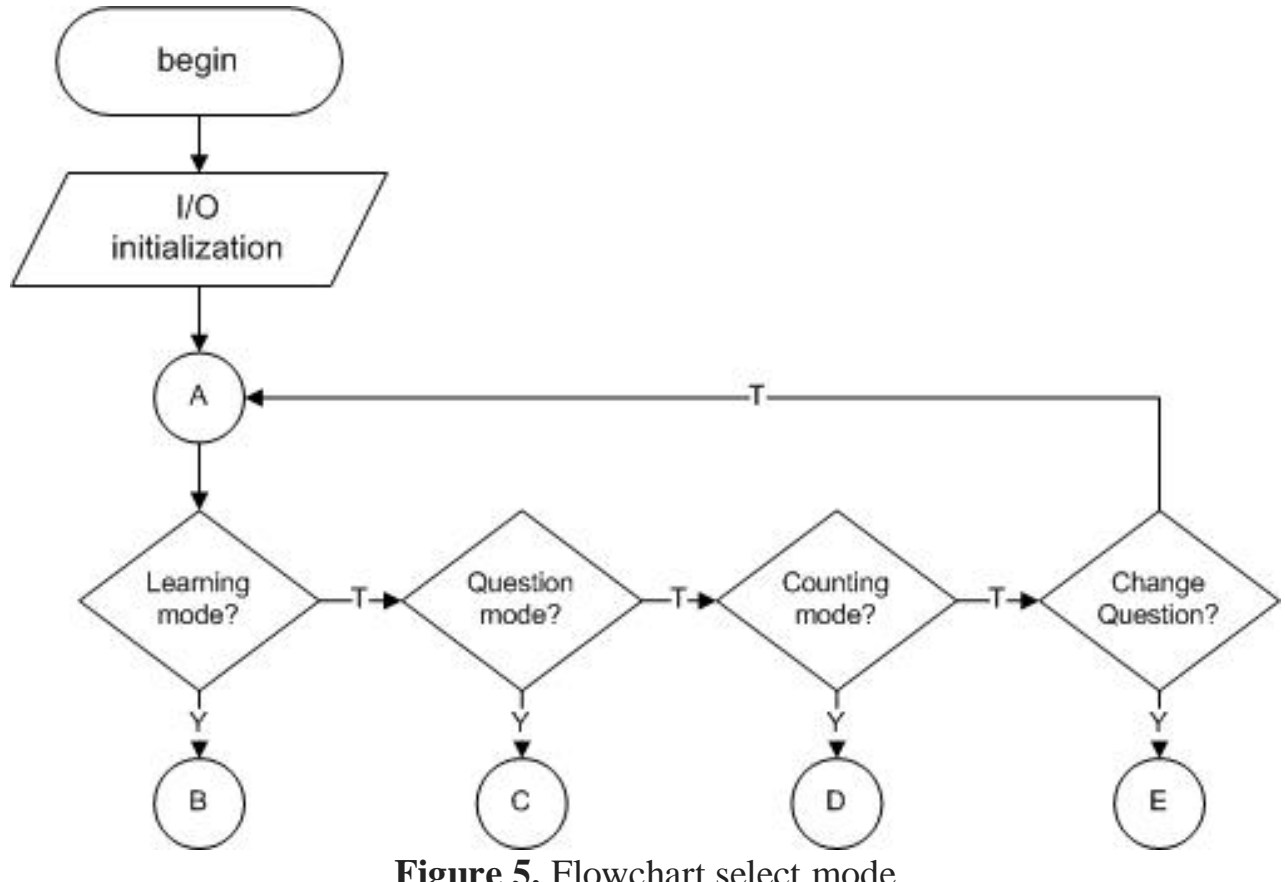

Figure 5. Flowchart select mode

When the learning machine starts, the program will wait for which mode is selected by early childhood whether learning mode, question mode or numeracy mode or by the teacher who may choose the question change mode. The learning mode flowchart is shown in Figure 6. 


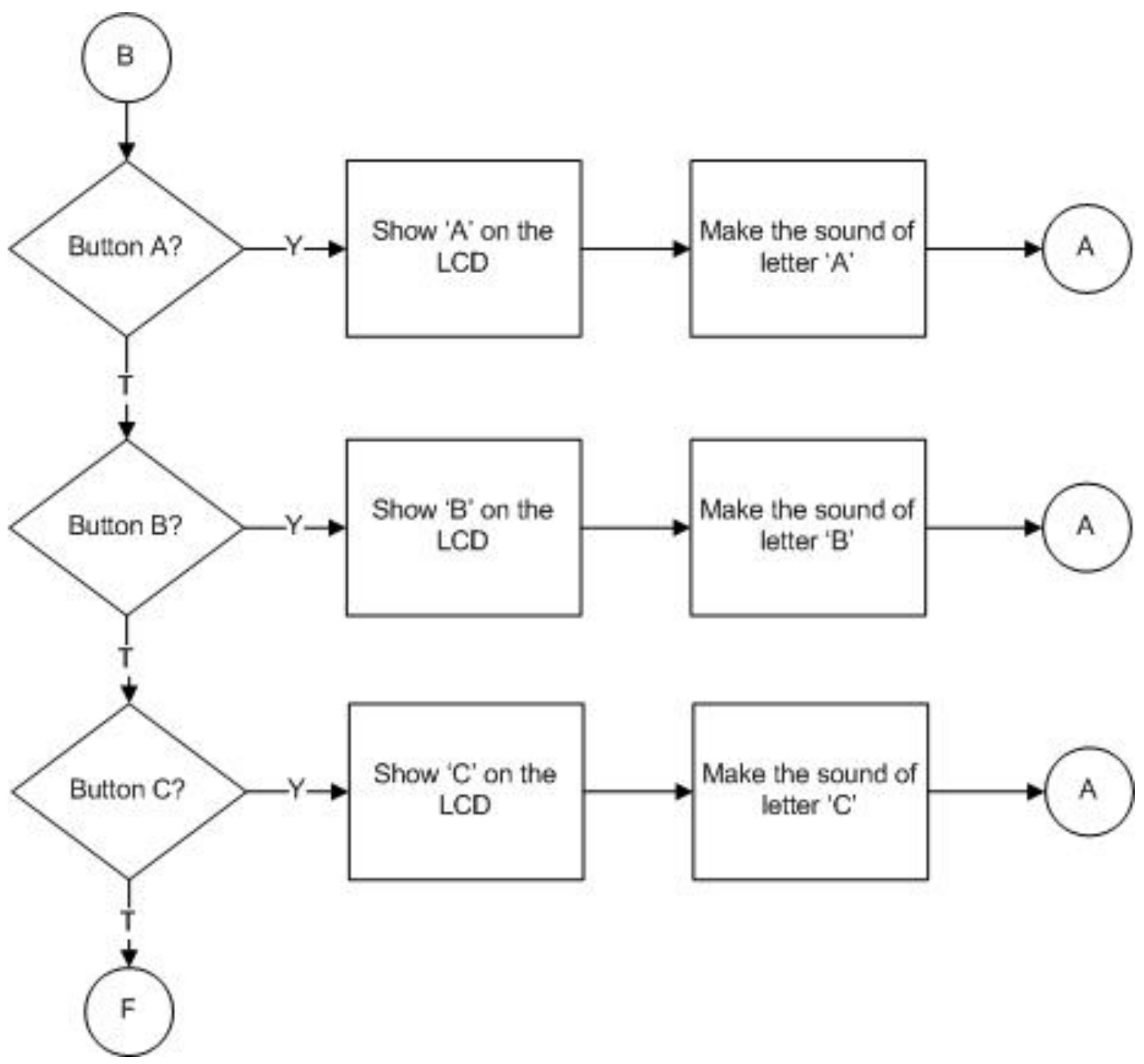

Figure 6. Flowchart learning mode 


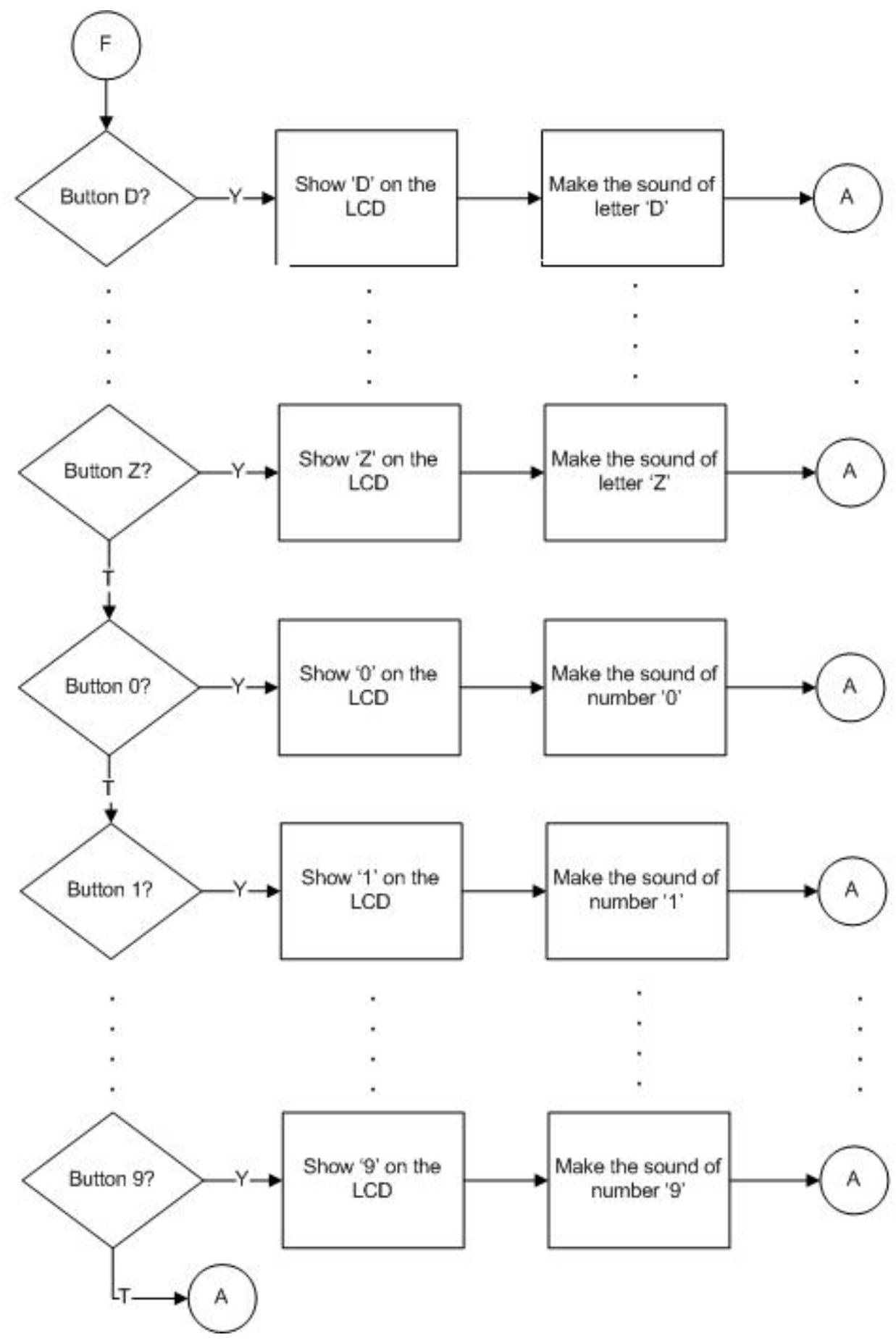

Figure 7. Flowchart learning mode (continue)

In the flowchart above, the program will scan one by one for each status of the key either the number key or the letter key. For example, when the number 9 key is pressed, the program will save it into a variable, display it on the LCD and Arduino will send commands to DF Player to play the corresponding $\mathrm{mp} 3$ file which in this case emits that the button pressed is a button with number 9. Next, the question mode flowchart is shown in Figure 8. 


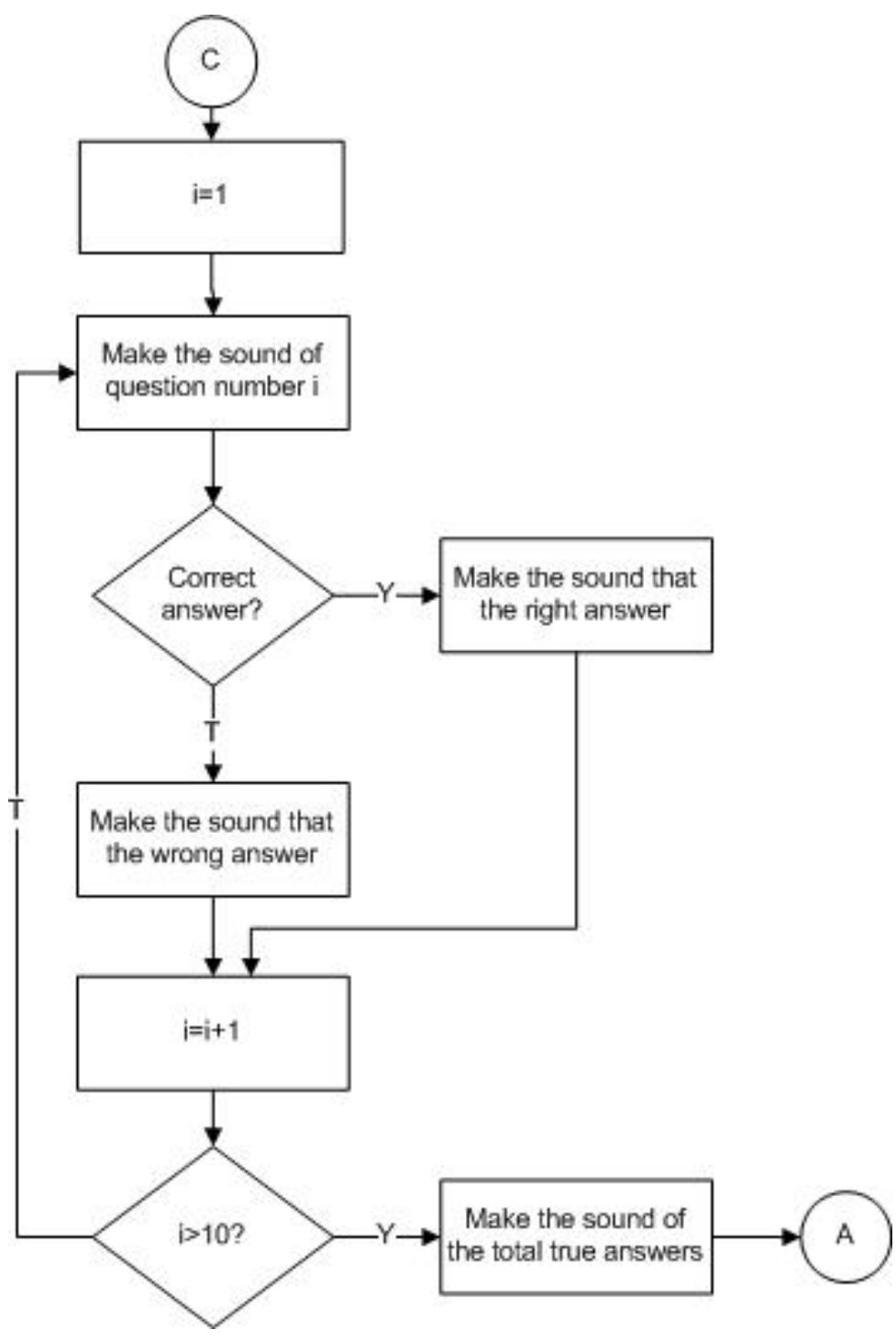

Figure 8. Flowchart question mode

In this question mode, the program will retrieve questions that are already stored in the Arduino EEPROM. The questions stored are only numbers, but these numbers represent the mp3 file numbers stored on the SD Card. Arduino will read a question and wait for answers from early childhood. After an answer is inputted by an early age child, the answer will be processed by Arduino to determine the correct or incorrect answer. If the answer is correct, then Arduino will instruct DF Player to play the mp3 file of the correct answer. If the answer is wrong, then Arduino will instruct DF Player to play the mp3 file with the wrong answer. This question answering process is repeated 10 times.

After all the questions are answered, then Arduino will count the number of correct answers then the sound related to the number of correct answers (values) will be voiced by this machine through DF Player and speakers. Next is the counting mode flowchart is shown in Figure 9. 


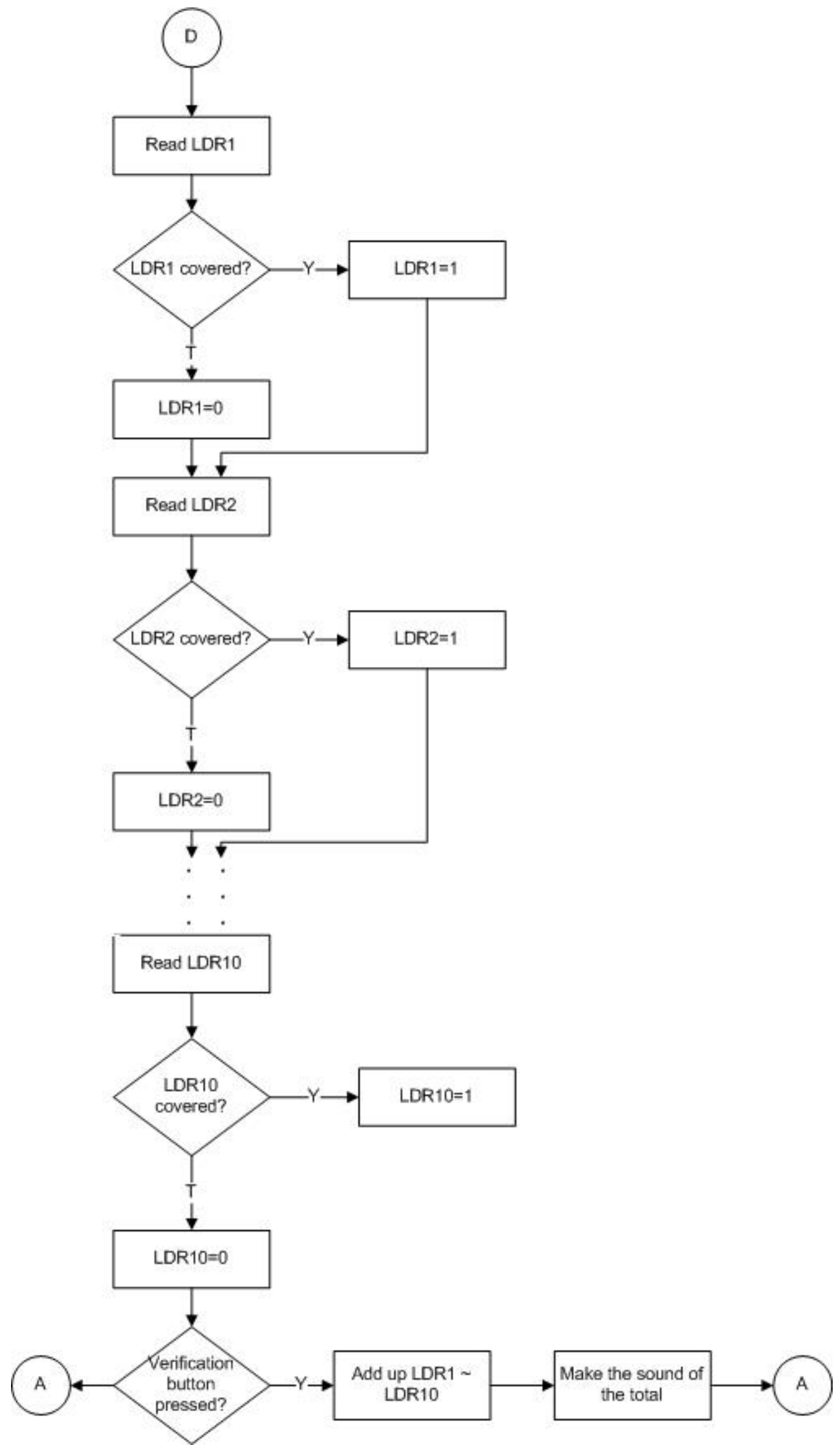

Figure 9. Flowchart counting mode

In this arithmetic mode, Arduino will repeatedly read each LDR status. If the LDR is closed then the corresponding variable will be given a value of 1 , instead, it is given a value of 0 . 
The process is repeated repeatedly until the verification button is pressed. If the verification button is pressed, all variables from LDR1 to LDR10 will be added up and the results will be released in the form of votes. The next flowchart is the question change mode flowchart shown in Figure 10.

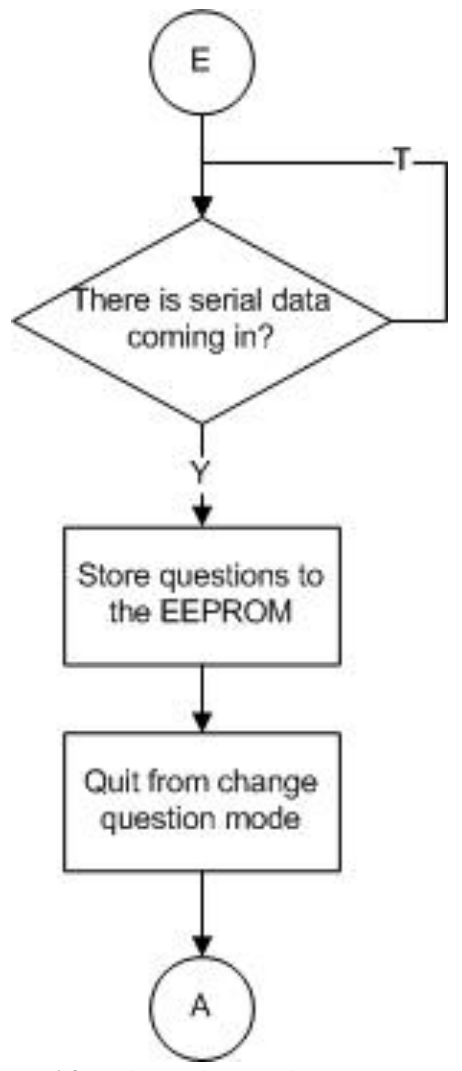

Figure 10. Flowchart change questions

When the user presses the change test button, Arduino will continue to wait for the serial input of the ESP8266 module. The question data from the android application will be received ESP8266 then sent to Arduino. Making the program for this hardware part using Language $\mathrm{C}$ and Arduino IDE where the main part of this program is the setup routine and loop routine ${ }^{[15]}$.

\section{RESULTS AND DISCUSSION}

Testing in this study was carried out to every mode on the machine, namely select mode, learning mode, question mode, count mode, and change problem mode. This test is carried out 5 times of trial in each mode.

\section{A.}

\section{Testing Select Mode}

In this test, a mode selection test using the 1, 2, 3 and 4 buttons is used. Table 1 shows the results of the test on this mode select operation.

Table 1. Test select mode

\begin{tabular}{|c|l|l|l|l|l|l|c|}
\hline \multirow{2}{*}{ No. Button } & \multirow{2}{*}{ Button Function } & \multicolumn{7}{|c|}{ Test } & \multirow{2}{*}{ Percentage } \\
\cline { 3 - 7 } & & 1 & 2 & 3 & 4 & 5 & \\
\hline 1 & Learning mode & $\sqrt{ }$ & $\sqrt{ }$ & $\sqrt{ }$ & $\sqrt{ }$ & $\sqrt{ }$ & $100 \%$ \\
\hline 2 & Question mode & $\sqrt{ }$ & $\sqrt{ }$ & $\sqrt{ }$ & $\sqrt{ }$ & $\sqrt{ }$ & $100 \%$ \\
\hline 3 & Counting mode & $\sqrt{ }$ & $\sqrt{ }$ & $\sqrt{ }$ & $\sqrt{ }$ & $\sqrt{ }$ & $100 \%$ \\
\hline 4 & Change questions mode & $\sqrt{ }$ & $\sqrt{ }$ & $\sqrt{ }$ & $\sqrt{ }$ & $\sqrt{ }$ & $100 \%$ \\
\hline
\end{tabular}


In this test, the device can be moved to a mode that corresponds to the button that is held and all tests carried out in this mode are $100 \%$ successful.

\section{B. $\quad$ Testing Learning Mode}

In this mode, all letter keys, numeric keys, LCD displays, and voice replacements are tested according to the flowchart and the program that was created. The test results for this learning mode are in table 2.

Table 2. Test learning mode

\begin{tabular}{|c|c|c|c|c|c|c|c|c|c|c|c|c|}
\hline \multirow[b]{2}{*}{ No. } & \multirow{2}{*}{ Button } & \multicolumn{2}{|c|}{ Testing 1} & \multicolumn{2}{|c|}{ Testing 2} & \multicolumn{2}{|c|}{ Testing 3} & \multicolumn{2}{|c|}{ Testing 4} & \multicolumn{2}{|c|}{ Testing 5} & \multirow{2}{*}{ Percentage } \\
\hline & & LCD & Sound & LCD & Sound & LCD & Sound & LCD & Sound & LCD & Sound & \\
\hline 1. & A & $\sqrt{ }$ & $\sqrt{ }$ & $\sqrt{ }$ & $\sqrt{ }$ & $\sqrt{ }$ & $\sqrt{ }$ & $\sqrt{ }$ & $\sqrt{ }$ & $\sqrt{ }$ & $\sqrt{ }$ & $100 \%$ \\
\hline 2. & $\mathrm{~B}$ & $\sqrt{ }$ & $\sqrt{ }$ & $\sqrt{ }$ & $\sqrt{ }$ & $\sqrt{ }$ & $\sqrt{ }$ & $\sqrt{ }$ & $\sqrt{ }$ & $\sqrt{ }$ & $\sqrt{ }$ & $100 \%$ \\
\hline 3. & $\mathrm{C}$ & $\sqrt{ }$ & $\sqrt{ }$ & $\sqrt{ }$ & $\sqrt{ }$ & $\sqrt{ }$ & $\sqrt{ }$ & $\sqrt{ }$ & $\sqrt{ }$ & $\sqrt{ }$ & $\sqrt{ }$ & $100 \%$ \\
\hline 4. & $\mathrm{D}$ & $\sqrt{ }$ & $\sqrt{ }$ & $\sqrt{ }$ & $\sqrt{ }$ & $\sqrt{ }$ & $\sqrt{ }$ & $\sqrt{ }$ & $\sqrt{ }$ & $\sqrt{ }$ & $\sqrt{ }$ & $100 \%$ \\
\hline 5. & $E$ & $\sqrt{ }$ & $\sqrt{ }$ & $\sqrt{ }$ & $\sqrt{ }$ & $\sqrt{ }$ & $\sqrt{ }$ & $\sqrt{ }$ & $\sqrt{ }$ & $\sqrt{ }$ & $\sqrt{ }$ & $100 \%$ \\
\hline 6. & $\mathrm{~F}$ & $\sqrt{ }$ & $\sqrt{ }$ & $\sqrt{ }$ & $\sqrt{ }$ & $\sqrt{ }$ & $\sqrt{ }$ & $\sqrt{ }$ & $\sqrt{ }$ & $\sqrt{ }$ & $\sqrt{ }$ & $100 \%$ \\
\hline 7. & G & $\sqrt{ }$ & $\sqrt{ }$ & $\sqrt{ }$ & $\sqrt{ }$ & $\sqrt{ }$ & $\sqrt{ }$ & $\sqrt{ }$ & $\sqrt{ }$ & $\sqrt{ }$ & $\sqrt{ }$ & $100 \%$ \\
\hline 8. & $\mathrm{H}$ & $\sqrt{ }$ & $\sqrt{ }$ & $\sqrt{ }$ & $\sqrt{ }$ & $\sqrt{ }$ & $\sqrt{ }$ & $\sqrt{ }$ & $\sqrt{ }$ & $\sqrt{ }$ & $\sqrt{ }$ & $100 \%$ \\
\hline 9 & I & $\sqrt{ }$ & $\sqrt{ }$ & $\sqrt{ }$ & $\sqrt{ }$ & $\sqrt{ }$ & $\sqrt{ }$ & $\sqrt{ }$ & $\sqrt{ }$ & $\sqrt{ }$ & $\sqrt{ }$ & $100 \%$ \\
\hline 10 & $\mathrm{~J}$ & $\sqrt{ }$ & $\sqrt{ }$ & $\sqrt{ }$ & $\sqrt{ }$ & $\sqrt{ }$ & $\sqrt{ }$ & $\sqrt{ }$ & $\sqrt{ }$ & $\sqrt{ }$ & $\sqrt{ }$ & $100 \%$ \\
\hline 11 & $\mathrm{~K}$ & $\sqrt{ }$ & $\sqrt{ }$ & $\sqrt{ }$ & $\sqrt{ }$ & $\sqrt{ }$ & $\sqrt{ }$ & $\sqrt{ }$ & $\sqrt{ }$ & $\sqrt{ }$ & $\sqrt{ }$ & $100 \%$ \\
\hline 12 & $\mathrm{~L}$ & $\sqrt{ }$ & $\sqrt{ }$ & $\sqrt{ }$ & $\sqrt{ }$ & $\sqrt{ }$ & $\sqrt{ }$ & $\sqrt{ }$ & $\sqrt{ }$ & $\sqrt{ }$ & $\sqrt{ }$ & $100 \%$ \\
\hline 13 & $\mathrm{M}$ & $\sqrt{ }$ & $\sqrt{ }$ & $\sqrt{ }$ & $\sqrt{ }$ & $\sqrt{ }$ & $\sqrt{ }$ & $\sqrt{ }$ & $\sqrt{ }$ & $\sqrt{ }$ & $\sqrt{ }$ & $100 \%$ \\
\hline 14 & $\mathrm{~N}$ & $\sqrt{ }$ & $\sqrt{ }$ & $\sqrt{ }$ & $\sqrt{ }$ & $\sqrt{ }$ & $\sqrt{ }$ & $\sqrt{ }$ & $\sqrt{ }$ & $\sqrt{ }$ & $\sqrt{ }$ & $100 \%$ \\
\hline 15 & $\mathrm{O}$ & $\sqrt{ }$ & $\sqrt{ }$ & $\sqrt{ }$ & $\sqrt{ }$ & $\sqrt{ }$ & $\sqrt{ }$ & $\sqrt{ }$ & $\sqrt{ }$ & $\sqrt{ }$ & $\sqrt{ }$ & $100 \%$ \\
\hline 16 & $\mathrm{P}$ & $\sqrt{ }$ & $\sqrt{ }$ & $\sqrt{ }$ & $\sqrt{ }$ & $\sqrt{ }$ & $\sqrt{ }$ & $\sqrt{ }$ & $\sqrt{ }$ & $\sqrt{ }$ & $\sqrt{ }$ & $100 \%$ \\
\hline 17 & $\mathrm{Q}$ & $\sqrt{ }$ & $\sqrt{ }$ & $\sqrt{ }$ & $\sqrt{ }$ & $\sqrt{ }$ & $\sqrt{ }$ & $\sqrt{ }$ & $\sqrt{ }$ & $\sqrt{ }$ & $\sqrt{ }$ & $100 \%$ \\
\hline 18 & $\mathrm{R}$ & $\sqrt{ }$ & $\sqrt{ }$ & $\sqrt{ }$ & $\sqrt{ }$ & $\sqrt{ }$ & $\sqrt{ }$ & $\sqrt{ }$ & $\sqrt{ }$ & $\sqrt{ }$ & $\sqrt{ }$ & $100 \%$ \\
\hline 19 & $S$ & $\sqrt{ }$ & $\sqrt{ }$ & $\sqrt{ }$ & $\sqrt{ }$ & $\sqrt{ }$ & $\sqrt{ }$ & $\sqrt{ }$ & $\sqrt{ }$ & $\sqrt{ }$ & $\sqrt{ }$ & $100 \%$ \\
\hline 20 & $\mathrm{~T}$ & $\sqrt{ }$ & $\sqrt{ }$ & $\sqrt{ }$ & $\sqrt{ }$ & $\sqrt{ }$ & $\sqrt{ }$ & $\sqrt{ }$ & $\sqrt{ }$ & $\sqrt{ }$ & $\sqrt{ }$ & $100 \%$ \\
\hline 21 & $\mathrm{U}$ & $\sqrt{ }$ & $\sqrt{ }$ & $\sqrt{ }$ & $\sqrt{ }$ & $\sqrt{ }$ & $\sqrt{ }$ & $\sqrt{ }$ & $\sqrt{ }$ & $\sqrt{ }$ & $\sqrt{ }$ & $100 \%$ \\
\hline 22 & $\mathrm{~V}$ & $\sqrt{ }$ & $\sqrt{ }$ & $\sqrt{ }$ & $\sqrt{ }$ & $\sqrt{ }$ & $\sqrt{ }$ & $\sqrt{ }$ & $\sqrt{ }$ & $\sqrt{ }$ & $\sqrt{ }$ & $100 \%$ \\
\hline 23 & $\mathrm{~W}$ & $\sqrt{ }$ & $\sqrt{ }$ & $\sqrt{ }$ & $\sqrt{ }$ & $\sqrt{ }$ & $\sqrt{ }$ & $\sqrt{ }$ & $\sqrt{ }$ & $\sqrt{ }$ & $\sqrt{ }$ & $100 \%$ \\
\hline 24 & $X$ & $\sqrt{ }$ & $\sqrt{ }$ & $\sqrt{ }$ & $\sqrt{ }$ & $\sqrt{ }$ & $\sqrt{ }$ & $\sqrt{ }$ & $\sqrt{ }$ & $\sqrt{ }$ & $\sqrt{ }$ & $100 \%$ \\
\hline 25 & $\mathrm{Y}$ & $\sqrt{ }$ & $\sqrt{ }$ & $\sqrt{ }$ & $\sqrt{ }$ & $\sqrt{ }$ & $\sqrt{ }$ & $\sqrt{ }$ & $\sqrt{ }$ & $\sqrt{ }$ & $\sqrt{ }$ & $100 \%$ \\
\hline 26 & $\mathrm{Z}$ & $\sqrt{ }$ & $\sqrt{ }$ & $\sqrt{ }$ & $\sqrt{ }$ & $\sqrt{ }$ & $\sqrt{ }$ & $\sqrt{ }$ & $\sqrt{ }$ & $\sqrt{ }$ & $\sqrt{ }$ & $100 \%$ \\
\hline 27 & 0 & $\sqrt{ }$ & $\sqrt{ }$ & $\sqrt{ }$ & $\sqrt{ }$ & $\sqrt{ }$ & $\sqrt{ }$ & $\sqrt{ }$ & $\sqrt{ }$ & $\sqrt{ }$ & $\sqrt{ }$ & $100 \%$ \\
\hline 28 & 1 & $\sqrt{ }$ & $\sqrt{ }$ & $\sqrt{ }$ & $\sqrt{ }$ & $\sqrt{ }$ & $\sqrt{ }$ & $\sqrt{ }$ & $\sqrt{ }$ & $\sqrt{ }$ & $\sqrt{ }$ & $100 \%$ \\
\hline 29 & 2 & $\sqrt{ }$ & $\sqrt{ }$ & $\sqrt{ }$ & $\sqrt{ }$ & $\sqrt{ }$ & $\sqrt{ }$ & $\sqrt{ }$ & $\sqrt{ }$ & $\sqrt{ }$ & $\sqrt{ }$ & $100 \%$ \\
\hline 30 & 3 & $\sqrt{ }$ & $\sqrt{ }$ & $\sqrt{ }$ & $\sqrt{ }$ & $\sqrt{ }$ & $\sqrt{ }$ & $\sqrt{ }$ & $\sqrt{ }$ & $\sqrt{ }$ & $\sqrt{ }$ & $100 \%$ \\
\hline 31 & 4 & $\sqrt{ }$ & $\sqrt{ }$ & $\sqrt{ }$ & $\sqrt{ }$ & $\sqrt{ }$ & $\sqrt{ }$ & $\sqrt{ }$ & $\sqrt{ }$ & $\sqrt{ }$ & $\sqrt{ }$ & $100 \%$ \\
\hline 32 & 5 & $\sqrt{ }$ & $\sqrt{ }$ & $\sqrt{ }$ & $\sqrt{ }$ & $\sqrt{ }$ & $\sqrt{ }$ & $\sqrt{ }$ & $\sqrt{ }$ & $\sqrt{ }$ & $\sqrt{ }$ & $100 \%$ \\
\hline 33 & 6 & $\sqrt{ }$ & $\sqrt{ }$ & $\sqrt{ }$ & $\sqrt{ }$ & $\sqrt{ }$ & $\sqrt{ }$ & $\sqrt{ }$ & $\sqrt{ }$ & $\sqrt{ }$ & $\sqrt{ }$ & $100 \%$ \\
\hline 34 & 7 & $\sqrt{ }$ & $\sqrt{ }$ & $\sqrt{ }$ & $\sqrt{ }$ & $\sqrt{ }$ & $\sqrt{ }$ & $\sqrt{ }$ & $\sqrt{ }$ & $\sqrt{ }$ & $\sqrt{ }$ & $100 \%$ \\
\hline 35 & 8 & $\sqrt{ }$ & $\sqrt{ }$ & $\sqrt{ }$ & $\sqrt{ }$ & $\sqrt{ }$ & $\sqrt{ }$ & $\sqrt{ }$ & $\sqrt{ }$ & $\sqrt{ }$ & $\sqrt{ }$ & $100 \%$ \\
\hline 36 & 9 & $\sqrt{ }$ & $\sqrt{ }$ & $\sqrt{ }$ & $\sqrt{ }$ & $\sqrt{ }$ & $\sqrt{ }$ & $\sqrt{ }$ & $\sqrt{ }$ & $\sqrt{ }$ & $\sqrt{ }$ & $100 \%$ \\
\hline
\end{tabular}

At each test conducted in this learning mode, when the button is pressed the letter or number form of the key appears on the LCD and the sound is related to the name of the letter or number is successfully issued by the device. The percentage of success in this mode is $100 \%$.

\section{C. $\quad$ Testing Question Mode}

The testing process in this mode is carried out according to the scenario of the flowchart and the program that has been made, whether the machine can determine the right or wrong answer and the machine can issue a value from the questions that have been answered. The test results for this mode are shown in table 3. 
ISSN : 1978 -8282, Online ISSN: 2655-4275

Table 3 Test question mode

\begin{tabular}{|c|c|c|c|c|c|c|c|c|c|c|c|c|}
\hline \multirow{2}{*}{ No. } & \multirow{2}{*}{ Question } & \multicolumn{10}{|c|}{ Testing Answer } & \multirow{2}{*}{ Percentage } \\
\hline & & $\mathrm{U}$ & $\mathrm{M}$ & $\mathrm{U}$ & $\mathrm{M}$ & $\mathrm{U}$ & $\mathrm{M}$ & $\bar{U}$ & $\mathrm{M}$ & $\overline{\mathrm{U}}$ & $\bar{M}$ & \\
\hline 1. & Mana huruf "Z"? & $\sqrt{ }$ & $\sqrt{ }$ & $\mathrm{x}$ & $\mathrm{X}$ & $\sqrt{ }$ & $\sqrt{ }$ & $\sqrt{ }$ & $\sqrt{ }$ & $\mathrm{X}$ & $\mathrm{x}$ & $100 \%$ \\
\hline 2. & Mana huruf "B"? & $\mathrm{x}$ & $\mathrm{x}$ & $\sqrt{ }$ & $\sqrt{ }$ & $\sqrt{ }$ & $\sqrt{ }$ & $\sqrt{ }$ & $\sqrt{ }$ & $\sqrt{ }$ & $\sqrt{ }$ & $100 \%$ \\
\hline 3. & Mana huruf "D"? & $\sqrt{ }$ & $\sqrt{ }$ & $\mathrm{x}$ & $\mathrm{X}$ & $\sqrt{ }$ & $\sqrt{ }$ & $\mathrm{X}$ & $\mathrm{x}$ & $\sqrt{ }$ & $\sqrt{ }$ & $100 \%$ \\
\hline 4. & Mana huruf "K"? & $\sqrt{ }$ & $\sqrt{ }$ & $\sqrt{ }$ & $\sqrt{ }$ & $\mathrm{X}$ & $\mathrm{X}$ & $\sqrt{ }$ & $\sqrt{ }$ & $\sqrt{ }$ & $\sqrt{ }$ & $100 \%$ \\
\hline 5. & Mana Angka "9"? & $\sqrt{ }$ & $\sqrt{ }$ & $\sqrt{ }$ & $\sqrt{ }$ & $\sqrt{ }$ & $\sqrt{ }$ & $\sqrt{ }$ & $\sqrt{ }$ & $\sqrt{ }$ & $\sqrt{ }$ & $100 \%$ \\
\hline 6. & Mana huruf "A"? & $\sqrt{ }$ & $\sqrt{ }$ & $\sqrt{ }$ & $\sqrt{ }$ & $\sqrt{ }$ & $\sqrt{ }$ & $\sqrt{ }$ & $\sqrt{ }$ & $\mathrm{X}$ & $\mathrm{x}$ & $100 \%$ \\
\hline 7. & Mana huruf "J"? & $\mathrm{X}$ & $\mathrm{x}$ & $\sqrt{ }$ & $\sqrt{ }$ & $\mathrm{x}$ & $\mathrm{x}$ & $\sqrt{ }$ & $\sqrt{ }$ & $\sqrt{ }$ & $\sqrt{ }$ & $100 \%$ \\
\hline 8. & Mana huruf "R"? & $\sqrt{ }$ & $\sqrt{ }$ & $\sqrt{ }$ & $\sqrt{ }$ & $\sqrt{ }$ & $\sqrt{ }$ & $\sqrt{ }$ & $\sqrt{ }$ & $\sqrt{ }$ & $\sqrt{ }$ & $100 \%$ \\
\hline 9. & Mana Angka "3"? & $\sqrt{ }$ & $\sqrt{ }$ & $\sqrt{ }$ & $\sqrt{ }$ & $\sqrt{ }$ & $\sqrt{ }$ & $\mathrm{x}$ & $\mathrm{x}$ & $\sqrt{ }$ & $\sqrt{ }$ & $100 \%$ \\
\hline 10. & Mana Angka "0"? & $\sqrt{ }$ & $\sqrt{ }$ & $\mathrm{x}$ & $\mathrm{x}$ & $\sqrt{ }$ & $\sqrt{ }$ & $\sqrt{ }$ & $\sqrt{ }$ & $\mathrm{X}$ & $\mathrm{x}$ & $100 \%$ \\
\hline & Total & \multicolumn{2}{|c|}{8} & & & & \multicolumn{2}{|c|}{7} & $100 \%$ \\
\hline
\end{tabular}

\section{Information:}

U User

M Machine

$\sqrt{ }$ given the correct answer by the user/machine declares true by voice

$x$ gave a wrong answer by the user/machine stating wrong by voice

In testing conducted for this question mode, it can be seen that the machine has succeeded in stating the right and wrong answers from users where in this case early childhood. When the answer given by pressing the button is correct, the machine will make a sound stating that the answer is correct and adding value 1 to the correct answer variable. Conversely, when a wrong answer the engine sounds that the answer is wrong. Finally, after all the questions are answered the machine will make a sound related to the total true value. In this mode, everything works $100 \%$.

\section{D. $\quad$ Testing Counting Mode}

Testing in this mode is done by placing ice cream sticks to the part that has been determined to cover the LDR. When the verification button is pressed, the machine will make a sound about the amount of LDR covered by the ice cream stick. Table 4 shows the results of testing this mode.

Table 4. Test counting mode

\begin{tabular}{|c|c|c|c|c|c|c|c|c|c|c|c|c|}
\hline \multirow{2}{*}{ Testing } & \multicolumn{10}{|c|}{ LDR } & \multirow{2}{*}{$\begin{array}{c}\text { Number and } \\
\text { Sound }\end{array}$} & \multirow{2}{*}{ Percentage } \\
\cline { 2 - 9 } & $\mathbf{1}$ & $\mathbf{2}$ & $\mathbf{3}$ & $\mathbf{4}$ & $\mathbf{5}$ & $\mathbf{6}$ & $\mathbf{7}$ & $\mathbf{8}$ & $\mathbf{9}$ & $\mathbf{1 0}$ & 9 & $100 \%$ \\
\hline 1 & $\sqrt{ }$ & $\sqrt{ }$ & $\sqrt{ }$ & $\sqrt{ }$ & $\sqrt{ }$ & $\mathrm{x}$ & $\sqrt{ }$ & $\sqrt{ }$ & $\sqrt{ }$ & $\sqrt{ }$ & 9 & $100 \%$ \\
\hline 2 & $\sqrt{ }$ & $\mathrm{x}$ & $\sqrt{ }$ & $\mathrm{x}$ & $\sqrt{ }$ & $\sqrt{ }$ & $\mathrm{x}$ & $\mathrm{x}$ & $\mathrm{x}$ & $\mathrm{x}$ & 4 & $100 \%$ \\
\hline 3 & $\mathrm{x}$ & $\sqrt{ }$ & $\sqrt{ }$ & $\mathrm{x}$ & $\mathrm{x}$ & $\sqrt{ }$ & $\sqrt{ }$ & $\mathrm{x}$ & $\sqrt{ }$ & $\sqrt{ }$ & 6 & 1 \\
\hline 4 & $\sqrt{ }$ & $\mathrm{x}$ & $\mathrm{x}$ & $\mathrm{x}$ & $\mathrm{x}$ & $\mathrm{x}$ & $\mathrm{x}$ & $\mathrm{x}$ & $\mathrm{x}$ & $\mathrm{x}$ & 1 & $100 \%$ \\
\hline 5 & $\sqrt{ }$ & $\sqrt{ }$ & $\mathrm{x}$ & $\sqrt{ }$ & $\sqrt{ }$ & $\mathrm{x}$ & $\sqrt{ }$ & $\sqrt{ }$ & $\mathrm{x}$ & $\sqrt{ }$ & 7 & $100 \%$ \\
\hline
\end{tabular}

From the test results, it appears that the machine can mention the number of ice cream sticks that cover the LDR sensor on the machine so that young children can find out the number of sticks placed on the machine.

\section{E. Testing Change Questions}

Testing in this mode is done to change the questions that will be stored on the Arduino Mega2560 EEPROM. The results of this test are shown in table 5.

Table 5. Test change questions

\begin{tabular}{|c|c|c|c|}
\hline $\begin{array}{c}\text { Test Send } \\
\text { Questions }\end{array}$ & Accepted ESP8266 & $\begin{array}{c}\text { Stored in } \\
\text { Arduino }\end{array}$ & Percentage \\
\hline 1 & $\sqrt{ }$ & $\sqrt{ }$ & $100 \%$ \\
\hline 2 & $\sqrt{ }$ & $\sqrt{ }$ & $100 \%$ \\
\hline 3 & $\sqrt{ }$ & $\sqrt{ }$ & $100 \%$ \\
\hline 4 & $\sqrt{ }$ & $\sqrt{ }$ & $100 \%$ \\
\hline 5 & $\sqrt{ }$ & $\sqrt{ }$ & $100 \%$ \\
\hline
\end{tabular}


From the results of the test mode change, this problem can be concluded that the machine can communicate to receive a sequence of new questions sent from the Android application. The percentage of success in this mode is $100 \%$.

\section{CONCLUSION}

This interactive letter and number learning machine is functioning properly in accordance with the results of the tests conducted in each mode where the operation select mode is $100 \%$ success rate, learning mode is $100 \%$ success rate, mode is about $100 \%$ success rate, count mode is $100 \%$ success rate and mode change successfully $100 \%$.

\section{SUGGESTED}

This research can be developed even better by adding a simple pronunciation of words or words that are often spoken by early childhood.

\section{REFERENCES}

[1] Moh Fauziddin, Mufarizuddin, 2018, "Useful of Clap Hand Games for Optimize cognitive Aspects in Early Childhood Education", Jurnal Obsesi: Jurnal Pendidikan Anak Usia Dini, Vol. 2 Issue 2 (2018) pp.162-169, p-ISSN: 2356-1327, e-ISSN: 2549-8959

[2] Fintri Indriyani, Kurniasih R Sihite, 2015, "Pengenalan Huruf, Angka dan Warna Pada Anak Usia Dini Melalui Pembelajaran Berbasis Multimedia", Jurnal Paradigma Vol. XVII, No. 1. Maret 2015 pp.28-35, ISSN: 2579-3500

[3] Asep Saefullah, Endang Sunandar, Muhammad Nur Rifai, 2017, "Prototipe Robot Pengantar Makanan Berbasis Arduino Mega Dengan Interface Web Browser", Jurnal CCIT, Vol.10 No.2 - Agustus 2017, ISSN : 1978 -8282, STMIK Raharja, Tangerang

[4] D. D. Dessai, G. B. Gonsalves, M. R. Luis, M. S. Cardoso, 2017, "Dark Detector System for Paper Waste Detection". IJSRD (International Journal for Scientific Research \& Development) Vol. 5, Issue 01 pp.873-875 ISSN (online): 2321-0613, IJSRD, India.

[5] G. Indraja, P. Ramesh, S.V.S Prasad, 2017, "Home Security and Safety System Using Arduino Mega 2560 Controller". International Journal of Research, Volume 04 Issue-17 pp. 453-458 December 2017, e-ISSN: 2348-6848 p-ISSN: 2348-795X, IJR, India

[6] Manan Mehta, 2015, "ESP8266: A Breakthrough in Wireless Sensor Networks and Internet of Things", International Journal of Electronics and Communication Engineering \& Technology (IJECET), Vol. 6, Issue 8, Agustus 2015, pp.07-11, p-ISSN: 0976-6464 e-ISSN: 0976-6472.

[7] Abhishek Gupta, Shriram Ojha, Vikash Kumar, Vikrant Singh, Vipin Malav, 2016, "Alcohol Detection with Vehicle Controlling", Vol.6, Issue 2, Maret-April 2016, pp.20-23, p-ISSN: 2394-6962 e-ISSN: 2250-0758.

[8] Pratiksha Bhuta, Karan Desai, Archita Keni, 2015, "Alcohol Detection and Vehicle Controlling", International Journal of Engineering Trends and Applications (IJETA), Vol. 2, Issue 2, Maret-April 2015, pp.92-97, ISSN: 2393-9516.

[9] Gouthami. C, Santosh. C, A. Pavan Kumar, Karthik. A, Ramya.K.R, 2016, "Design and Implementation of Automatic Street Light Control System using Light Dependent Resistor", International Journal of Engineering Trends and Technology (IJETT),Vol. 35 No. 10, Mei 2016 pp.465-470. ISSN: 2231-5381.

[10] Angga Khalifah Tsauqi, Murtezha Hadijaya el, Ivander Manuel, Venas Miftah Hasan, Annisa Tsalsabila, Fadhilah Chandra, Titin Yuliana, Putri Tarigan, Irzaman, 2016, "Saklar Otomatis Berbasis Light Dependent Resistor (Ldr) Pada Mikrokontroler Arduino Uno", Prosiding Seminar Nasional Fisika (E-Journal) SNF2016, Vol. V Oktober 2016, pp19-24, pISSN: 2339-0654 e-ISSN: 2476-9398.

[11] Gurpreet kour, Rajesh Mehra, 2016, "Power and Area Efficient Design of Priority Encoder using $90 \mathrm{~mm}$ Technology", International Journal of Engineering Trends and Technology (IJETT),Vol. 36 No. 5, Juni 2016 pp.261-265. ISSN: 2231-5381. 
[12] M F Wicaksono, Hidayat. 2017, "Mudah Belajar Mikrokontroler Arduino Disertai 23 Proyek, termasuk Proyek Ethernet dan Wireless Client Server". Bandung: Informatika, 2017

[13] F. Andika, J. Kustija, 2017, "Nominal of Money and Colour Detector for the Blind People". International Symposium on Materials and Electrical Engineering (ISMEE) 2017. IOP Conf. Series: Materials Science and Engineering 384 (2018) 012023 doi:10.1088/1757899X/384/1/012023

[14] Nilesh Gode, Rushabh R. Bari, Sakshat R. Bhoir, Abhishek R. Deokar, Nikhil T. Av, 2017, "Ultra-Low Frequency Amplification using Class D Topology", International Journal for Scientific Research \& Development, Vol. 5, Issue 01, ISSN (online): 2321-0613, IJSRD, India.

[15] I. Eka Mulyana, Rindi Kharisman, 2014, "Perancangan Alat Peringatan Dini Bahaya Banjir dengan Mikrokontroler Arduino Uno R3”, CITEC JOURNAL, Vol. 1, No. 3, Mei 2014 - Juli 2014 ISSN: 2354-5771, STMIK AMIKOM, Yogyakarta 